\title{
The Adaptive Market Hypothesis and the Day-of-the-Week Effect in African Stock Markets: the Markov Switching Model
}

\author{
Adefemi A. Obalade \\ School of Accounting, Economics \& Finance, University of KwaZulu-Natal Durban \\ South Africa, Assistant Lecturer at Ekiti State University, Ado-Ekiti, Nigeria \\ e-mail: obaladeadefemi@yahoo.com
}

\author{
Paul-Francois Muzindutsi \\ Ph.D., Associate Professor, School of Accounting \\ Economics \& Finance University of KwaZulu-Natal, Durban, South Africa \\ e-mail: muzindutsip@ukzn.ac.za (corresponding author)
}

\section{Abstract}

In line with the Adaptive Market Hypothesis (AMH), the objective of this study is to investigate how the day-of-the-week (DOW) effect behaves under different bull and bear market conditions in African stock markets, and to examine the likelihood of being in a bull or bear regime for each market. A Markov Switching Model (MSM) was employed as the analytical technique. The results show that the DOW effect appears in one regime and disappears in another, in all markets, as rooted in the AMH. Lastly, all markets, except the Johannesburg Stock Exchange have a higher tendency to be in a bearish state than a bullish one. Our findings show that active investment management may yield profits for investors investing in most African markets during bearish conditions.

Keywords: calendar effect, AMH, African stock markets, Markov Switching Model

JEL: G10, G14 


\section{Introduction}

The Efficient Market Hypothesis (EMH) is the most popular asset pricing theory in the field of finance. The theory posits that security prices fully reflect all obtainable information. The implication is that past prices should have no predictive power over future prices; hence, successive stock returns should be random (Fama 1970). However, several deviations and various types of patterns have been discovered in asset returns, which are at variance with the EMH and, hence, are termed efficient market anomalies. Lo, Blume, and Durlauf (2007) identified calendar anomalies as one such group of contradictions to the EMH. Alagidede (2013) defined calendar anomalies as the likelihood that returns on financial securities exhibit systematic patterns during a particular time of the day, week, month, or year. The hype of calendar anomalies is as a result of investors seeking gainful trading strategies in order to take advantage of any identifiable pattern. Calendar anomalies or effects consist of day-of-the-week (DOW), end-of-the-week, holidays, January, month-of-the-year, turn-of-the-year, turn-of-the-month, intra-month/half-of-the-month, lunar (moon) and Halloween (summer/winter) effects. Consequent to the introduction of emotions and irrationality in the field of finance, calendar anomalies have been placed under the umbrella of behavioral finance (BF). Thus, the presence of calendar anomalies is one of the signals of a stock market's inefficiency. This means that calendar anomalies form part of the controversies that exist between the Efficient Market and BF schools as to whether stock markets are efficient.

The Adaptive Market Hypothesis (AMH) emerged in the early 2000s as a middle of the road approach between the EMH and the behavioral schools of thoughts. The new school states that investors are intelligent but fallible, and they learn and adapt to dynamic market environments (Lo 2012). Thus, markets are not efficient at all times but are usually competitive and adaptive, varying in their magnitude of efficiency as the environment and participants vary through time. Like the EMH, the AMH suggests that market participants act in their own interests. However, unlike the EMH, in which it is believed that individuals operate in a stationary and equilibrium market environment, and hence do not make mistake, the AMH holds that individuals make frequent mistakes, but they have the capability to learn from them and adapt their behavior accordingly (Lo 2005). The AMH explains that adaptation and innovation are driven by competitive forces in the market and that the interaction among competitors is governed by the survival of the richest (natural selection) (Lo 2005).

Lastly, all the stages beginning with selfish individuals through competition, adaptation, and natural selection to environmental conditions, describe the market dynamics under the AMH. Lo (2004 2005) holds that market efficiency is not an all or nothing phenomenon as the stock market evolves over time, and periods of inefficiency alternate with periods of efficiency, subject to changing profit opportunities, market conditions as well as the nature and number of market participants. Thus, AMH provides an argument for the coexistence of market efficiency and anomalies. If the AMH states that efficiency is fluctuating, do market anomalies also fluctuate? If efficiency is affected by market conditions, are market anomalies also affected by market conditions? These 
are important questions that require empirical investigation. Urquhart and McGroarty (2014) attempted to investigate the presence of market anomalies under AMH in the US context, but it remains to be seen how calendar anomalies behave under different market conditions in smaller or emerging markets, such as African stock markets.

Therefore, the current study investigates one of the most common calendar anomalies, known as the DOW or weekend (Monday/Friday) effects, in the African stock markets using a regime-switching methodology. The DOW effect is the tendency for stock returns to be abnormally higher on some days of the week than on other days, often in a recurring pattern over the years (Magnus 2008; Hassan et al. 2015). It explains that the expected or standardized returns are different for all weekdays. For instance, the Friday anomaly compares the previous trading day's closing price return, i.e., Thursday's, to Friday's closing price, and similarly for the other days (Hansen 2003). Pandey and Samanta (2016) stated that the DOW effect is evidenced by significantly different returns on some weekdays; notably larger on a Friday and lower on a Monday. According to Dragan, Martin, and Igor (2012), the DOW effect is like the weekend effect. It holds that securities displayed much smaller returns in the period between Friday's close and Monday's close. There is a need to examine the DOW effect within the AMH framework since most of the earlier studies did not take the possibility of a switch in behavior and market conditions into consideration. Thus, the objective of the study is to investigate how the DOW effect behaves under different bull and bear market conditions in the selected African stock markets.

\section{Literature Review}

Market participants are presumed to be rational in financial theory. However, they make certain decisions quickly, without enough information or time. Factors such as fears, desires, and emotions influence investors' decisions (Helena 2009). In practice, investors take their feelings into consideration, suggesting that markets may not reflect economic fundamentals in certain situations (Goedhart et al. 2005). One of the situations is irrational behavior, such as optimism and pessimism. Another situation is regular patterns of behavior, such as overconfidence and overreaction. Behavioral finance provides relevant explanations for calendar anomalies. The investor's psychology hypothesis, for instance, states that market participants tend to purchase securities as holidays approach due to verve and holiday excitement (Brockman and Michayluk 1998; Vergin and McGinnis 1999; Marrett and Worthington 2006). This behavioral argument is consistent with the notion that happier people tend to believe in more positive outcomes (Thaler 1999). Thus, investors may occasionally act irrationally because the differences in their moods during different days of the week may result in varying levels of optimism and pessimism on these days of the week, hence differing returns on securities (Rystrom and Benson 1989; Rossi 2007). Normally, investors are less optimistic on Mondays relative to other weekdays, and optimistic on Fridays, and as a result, they purchase shares and create a rising swing in prices (Rystrom and Benson 1989). 
Another explanation for the negative weekend effect is rooted in the Settlement Regime Hypothesis, which holds that the delay between the trade date and the settlement date creates an interest-free loan until the settlement (Lakonishok and Levi 1982). Friday buyers get two extra days of free credit, creating an incentive to buy on Fridays and pushing Friday prices up (Gibbons and Hess 1981). French (1980) explained the information release hypothesis and showed that firms and governments generally release good news between Monday and Friday but wait until the weekend to release bad news. As a result, the bad news is reflected in lower stock prices on Mondays, while the good news is reflected in higher stock prices on Fridays. However, in an efficient market, rational investors should recognize this and should short sell on Friday at a higher price and buy on Monday at a lower price, assuming that the expected profit covers the transaction costs and payment for risk. This type of trading should lead to the elimination of the anomaly since it should result in prices falling on Friday and rising on Monday.

Rossi (2007) examined the calendar anomalies in South American stock returns from 1997 to 2006, focusing on the existence of DOW effects and the monthly patterns in Argentina, Brazil, Chile, and Mexico. It was concluded that there was a traditional positive Friday effect in Brazil and in Chile, with lowest returns on Mondays. In addition, the study documented positive returns on Wednesdays and Fridays. In Mexico, the highest returns appeared on Wednesdays. For Argentina, there was no record of a DOW anomaly. A negative Monday effect and positive Wednesday effect was also found by Shiok, Chong, and Brian (2007), in Malaysia. Similarly, Hakan and Halil (2001) examined the DOW effect on stock market volatility in the S\&P 500 market index from January 1973 to October 1997 and found that the DOWeffect is present in both volatility and return equations. While the highest and lowest returns were observed on Wednesday and Monday, the highest and lowest volatilities were observed on Friday and Wednesday, respectively. Further investigation of sub-periods reinforces the findings that the volatility pattern across the days of the week is statistically different.

Wing-Keung, Aman, and Nee-Tat (2006) investigated calendar anomalies in Singapore using the full period over 1993-2005 and sub-periods of 1993-1997 and 1998-2005. The results showed that there is a January effect in the post-2007 financial crisis period, but the weekend and holiday effects disappear post-crisis. The changing behavior reported here has implication for the AMH. Lukas (2009) employed rolling and extended dummy variable regression to analyze calendar effects in Germany and 28 other countries from 1955 to 2009, and submitted that the DOW effect started disappearing in the late 1990s, which is suggestive of the new AMH. In a comprehensive review of the literature on calendar anomalies between 1915 and 2009, Martin (2011) concluded that the weekend effect seems to have disappeared, and the January effect has halved. Lukas (2012) investigated seasonality in the US stock exchange across six major industrial sectors. The results rejected the DOW and January effects in the US stock market, thus pointing to changing behavior since these anomalies were established by previous studies.

Africa-related studies include Osazevbaru and Oboreh (2014), which established the presence of the Monday effect in Nigeria. Meanwhile, Julio and Beatriz (2013), studying 
Colombian, Indonesian, Vietnamese, Egyptian, Turkish, and South African stock returns, found evidence of the DOW effect. Bundoo (2011), in the Mauritian Stock market, found negative Tuesday returns but positive returns for other days of the week, with significant Friday and September effects. Alagidede and Panagiotidis (2006) analyzed the calendar effect of the Ghana Stock Exchange using daily closing prices and found the presence of April and weekend effects. Brishan (2012) examined sectoral calendar anomalies in the Johannesburg Stock Exchange (JSE), and concluded that there is the presence of day and month effects, reducing pre-holiday effects, and the absence of weekend or January anomalies. Umar (2013) documented different DOW effects in Nigeria and South Africa, pre and post-stock market liberalization. The South African market exhibits a significant DOW effect on Mondays and Fridays pre-liberalization and on Thursdays and Fridays, respectively, in the mean and variance equation post-liberalization. Based on skewness and kurtosis of the daily index from 2004 to 2008, Shakeel, Douglas, and Chimwemwe (2013) submitted that Zambia, Botswana, Nigeria, and Morocco displayed significantly different DOW effects in the pre and post financial crisis periods while South Africa did not. Urquhart and McGroarty (2014) was the first study to investigate time-varying calendar anomalies within the AMH framework in the US using daily and monthly indexes from 1900 to 2013. Their findings show that calendar anomalies vary over time and are influenced by conditions such as up, down, bull, bear, normal, expansionary and contractionary, or Republican and Democrat dispensations. In line with the AMH, calendar anomalies could also be investigated vis-à-vis market conditions. There is a dearth of studies on the explanatory power of market conditions on the behavior of calendar anomalies in stock markets, especially in small stock markets such as African stock markets.

\section{Research Methodology}

\section{Data and Sampling}

The daily stock market return indices of the major stock markets in Africa were used in this study. The use of daily data made it possible to investigate the DOW effect in stock returns. The data covered a period of 20 years (1998-2017), which was selected based on data availability. The data were sourced from the Bloomberg database. The study used a sample of five African stock markets, namely Nigeria, South Africa, Mauritius, Morocco, and Tunisia. The selection of these markets is based on data availability and their relative size in the continent. The big markets in the region are in South Africa, with a market capitalization above $\$ 970$ billion and 388 listings, Nigeria with a market capitalization above $\$ 114$ billion and 190 listings, and Morocco with a market capitalization of $\$ 54.8$ billion and 75 listings. The stock markets in Mauritius and Tunisia are small with about $\$ 8.5$ billion and 8.6 billion market capitalizations, respectively (AfricaTLF.com 2016). For the Nigerian Stock Exchange All-Share Index (NGSEINDX), the JSE All Share Index (JALSH), the Stock Exchange of Mauritius (SEM) All-Share Index (SEMDEX), the Casablanca stock exchange 
(MOSE) All-Share Index (MOSENEW) and the Tunisia Stock Exchange All-Share Index (TUSISE), simple returns were calculated using the following formula:

$$
I_{t}=\left(\frac{P_{t}-P_{t-1}}{P_{t-1}}\right) \times 100
$$

Where $\mathrm{IR}_{\mathrm{t}}$ is the stock index return at time $\mathrm{t}$, and $\mathrm{P}_{\mathrm{t}}$ and $\mathrm{P}_{\mathrm{t}-1}$ are the time $t$ and $t-_{1}$ stock price indices. Figure 1 plots the time series of the indices' returns of the five African markets, which is clearly characterized by volatility clustering. Volatility clustering describes the tendency of large changes in asset prices (of either sign) to follow large changes, and vice versa (Brooks 2014). Volatility clustering provides additional motivation for a nonlinear model such as the Markov Switching Model MSM.

NGSEINDX

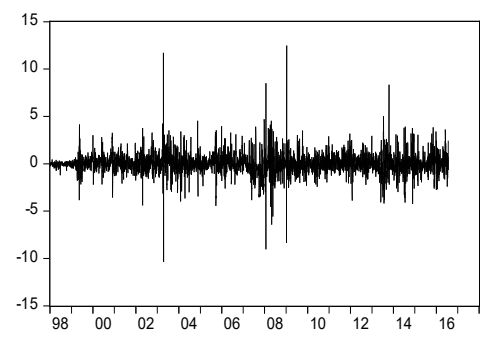

SEMDEX

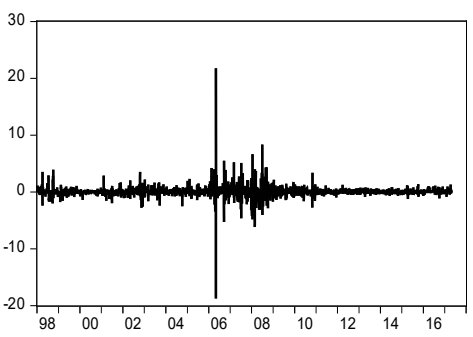

TUSISE

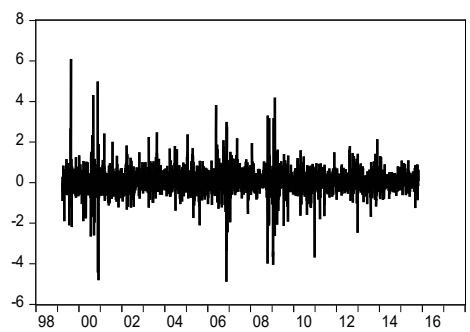

JALSH

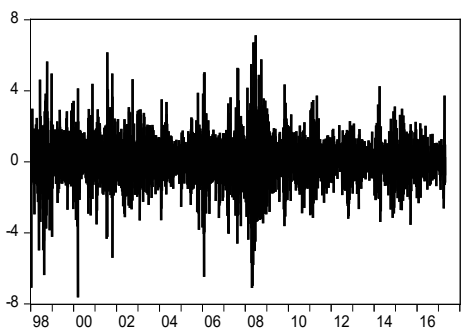

MOSENEW

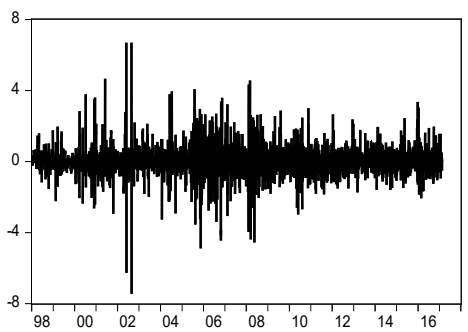

Figure 1. Daily Stock Returns from 1998:1-2018:2 Source: authors' computation (2018). 


\section{The Day-of-the-Week Effect Model}

The MSM was estimated with a dummy regression, which is a popular model for estimating DOW effects. The dummy regression is given in Equation 2.

$$
D I R_{t}=\sum_{i=1}^{5} \beta_{i} D_{i}+\varepsilon_{t} \quad H_{0}: \beta_{i}=0 \text { and } H_{1}: \beta_{i} \neq 0
$$

Where $D I R_{t}$ is the index returns on day $t, D_{1}$ is the dummy variable which takes a value of 1 if $t$ is Monday and 0 if not, $D_{2}$ is the dummy variable which takes a value of 1 if $t$ is Tuesday and 0 if not, and so on. $\beta_{i}$ (where $\mathrm{i}=1,2 \ldots . .5$ ) represent the coefficients to be estimated. The hypothesis is tested for each day using t-statistics. If there is any seasonal effect in a given day, it will be indicated by a statistically significant dummy coefficient for that day. Note that $\beta_{1}$ must be negative (low) and $\beta_{5}$ must be positive (high) for the popular weekend effect to exist.

\section{The Regime Switching Model}

One method of analyzing calendar anomalies under different market conditions (bull, bear) is to subject stock market returns to a regime switching model. Suppose that the stock return $R_{t}$ follows a process that depends on the value of an unobserved discrete state variable $S_{t}$. We assume that there are $M$ possible regimes and that the process is said to be in state or regime $m$ in period $t$ when $s_{t}=m$, for $m=1,2, . ., M$. The switching model associates a different regression model with each regime. We defined a simple model with a regime switching intercept and regressors as follows:

$$
D R_{t}=\mu_{s_{t}}+\sum_{i=1}^{5} \alpha_{i s_{t}} D_{i}+\varepsilon_{s_{t, t}}
$$

Where $D R_{t}$ is index returns, $\mu_{s_{t}}$ is the state-dependent intercept, $s_{t}$ are states, $D_{i}(i=1,2,3,4,5$ for DOW $)$ are calendar dummy variables with state-dependent coefficients $\alpha_{s_{t}}$, and $\varepsilon_{s_{t, t}}$ is the error term. Markov switching regression can generate $\mathrm{M}$ regression models, associating a different model with each regime (bull or bear) and showing under which regime calendar anomalies are significant. Since we introduce as many dummy variables as the number of categories of that variable (calendar day), we must drop the intercept to avoid the dummy variable trap from Equation 3. Doing so, the model becomes:

$$
D R_{t}=\sum_{i=1}^{5} \alpha_{i s_{t}} D_{i}+\varepsilon_{t}
$$


The persistence of each regime follows a first-order Markov process given by the transition probability matrix. The first-order Markov assumes that the probability of being in a state depends on the most recent state, so that

$$
P\left(s_{t}=j s_{t-1}=i\right)=p_{i j}(t)
$$

Where the $i j$-th element is the probability of moving from regime $i$ in period $t-1$ to regime $j$ in period $t$. The probabilities are assumed to be constant so that $p_{i j}(t)=p_{i j}$ for all periods. For a two-regime model, the matrix takes the following form:

$$
P=\begin{array}{lll}
P\left(s_{t}=0 / s_{t-1}=0\right) & P\left(s_{t}=1 / s_{t-1}=0\right) \\
P\left(s_{t}=0 / s_{t-1}=1\right) & P\left(s_{t}=1 / s_{t-1}=1\right)
\end{array}=\begin{array}{ll}
P 00 & P 01 \\
P 10 & P 11
\end{array}
$$

Where $P 00$ is the probability that the return is at state 0 (low) at time $t-1$ and remains there at time $t, P 01$ is the probability that the return is at state 0 at time $t-1$ and moves to 1 (high) at time $t . P 10$ is the probability that the return is at state 1 at time $t-1$ and moves to state 0 at time $t$, and $P 11$ is the probability that the return is at state 1 at time $t-1$ and remains there at time $t$ (Brooks 2014).

The probability of a change from regime $i$ to $j$ follows a logistic model. Therefore, each row of the transition matrix specified contains a full set of conditional probabilities. Thus, a separate multinomial logit model can be specified for each row of the transition matrix as given in Equation 7:

$$
P_{m}\left(G_{t-1}, d_{i}\right)=\frac{\exp \left(G_{t-1}^{\prime}, d_{i j}\right)}{\sum_{s=1}^{M} \exp \left(G_{t-1}^{\prime}, d_{i s}\right)}
$$

for $\mathrm{j}=1, \ldots, \mathrm{M}$ and $\mathrm{i}=1, \ldots, \mathrm{M}$ with the normalizations $d_{i M}=0$. Markov switching models are normally and generally specified with constant probabilities so that $G_{t-1}$ contains only a constant. Hamilton's (1989) model of GDP, which is a popular case of a constant transition probability specification, is adopted for this study. Alternatively, Diebold, Lee, and Weinbach (1994), and Filardo (1994) adopt two-state models that employ time-varying logistic parameterised probabilities. However, the Markov switching specification of Hamilton (1989) is naturally a benchmark in this class of models (Perlin 2015). 


\section{Empirical Results}

\section{Descriptive Statistics and Difference in Mean}

Descriptive statistics of return indices for the full sample period and rolling window analyses are found in Table 1. It shows that the JALSH, followed by the NGSEINDX, have the highest mean return and volatility. MOSENEW has the lowest mean return, while the remaining two markets are similar. The least volatile return is found in the TUSISE while the SEMDEX and the MOSENEW are identical in terms of volatility. Four of the five markets are positively skewed in the full sample period. Only the JALSH has a longer left tail compared to the mean values with negative skewness. The kurtoses are positive and greater than 3 for all markets, which is expected for normal distribution. It means that indices' returns are peaked relative to a normal distribution, and hence leptokurtic. The SEMDEX has the highest leptokurtic distribution, while the JALSH has the lowest. For further confirmation of the non-normality of the series, as shown by skewness and kurtosis, the Jarque-Bera (JB) test of normality is carried out. The $p$-values of the JB test are less than 1 percent, which rejects the null hypothesis of the normal distribution of the return series. Hence, the return series of the five markets are not normally distributed.

Table 1. Descriptive Statistics of Daily Returns

\begin{tabular}{|l|l|c|c|c|c|c|}
\hline \multicolumn{1}{|c|}{ INDICES } & \multicolumn{1}{c|}{ Mean } & SD & Skewness & Kurtosis & JB & KW \\
\hline NGSEINDX & 0.05142 & 1.06669 & 0.44666 & 17.1562 & $40574.6^{* * *}$ & $10.99735^{* * *}$ \\
\hline JALSH & 0.06641 & 1.22757 & -0.15394 & 6.58679 & $2720.49^{* * *}$ & $15.93906^{* * *}$ \\
\hline SEMDEX & 0.04508 & 0.75210 & 2.08949 & 229.286 & $1074825^{* * *}$ & $14.87634^{* * *}$ \\
\hline MOSENEW & 0.0324 & 0.75300 & 0.01799 & 13.3226 & $22150.5^{* * *}$ & 6.314256 \\
\hline TUSISE & 0.04762 & 0.57115 & 0.05672 & 17.9064 & $39183.6^{* * *}$ & $31.21066^{* * *}$ \\
\hline
\end{tabular}

*** symbolises significance(p-values) at 1\%

Source: authors' computation (2018).

Kruskal-Wallis is a test of no difference in the DOW mean return. The results of this test in Table 1show that the NGSEINDX, JALSH, SEMDEX, and TUSISE DOW returns are significantly different; hence, the hypothesis of no significant difference in the mean is rejected. The existence of these differences implies market inefficiency.

\section{Transition Probabilities and Constant Expected Durations}

Table 2 contains the transition probability of being in a bullish or bearish market for each of the markets under investigation. The probability of being in a bear regime (0.955858) is higher than the probability of being in a bull regime (0.880094). Thus, the NGSEINDX has a higher tendency of undergoing a bearish market than a bullish 
market. Hence, the NGSEINDX is expected to spend approximately 23 days in a bear regime and eight days in a bull regime, as revealed by the constant expected duration. The transition probabilities of the JALSH following bearish and bullish trends are 0.968184 and 0.986577 , respectively. This implies that the JSE spends more time in a bull market than a bear market condition. This is corroborated by the constant expected duration of approximately 74 days in regime 2 compared to 31 days in regime 1 . The JSE, therefore, stays in a bull regime more than double the period spent in a bear regime.

Table 2. Transition probabilities \& Constant expected durations

\begin{tabular}{|c|c|c|c|c|}
\hline \multicolumn{5}{|c|}{ Transition probabilities \& Constant expected durations } \\
\hline \multicolumn{3}{|c|}{ NGSEINDX } & \multicolumn{2}{|c|}{ JALSH } \\
\hline $\begin{array}{c}\text { Transition } \\
\text { probabilities }\end{array}$ & Regime $1_{(t-1)}$ & Regime $2_{(t)}$ & Regime $1_{(t-1)}$ & Regime $2_{(t)}$ \\
\hline Regime $1_{(t-1)}$ & 0.955858 & 0.044142 & 0.968184 & 0.031816 \\
\hline Regime $2_{(\mathrm{t})}$ & 0.119906 & 0.880094 & 0.013423 & 0.986577 \\
\hline \multirow[t]{2}{*}{$\begin{array}{l}\text { Constant } \\
\text { expected } \\
\text { durations }\end{array}$} & 22.65396 & 8.339853 & 31.43073 & 74.49844 \\
\hline & \multicolumn{2}{|c|}{ SEMDEX } & \multicolumn{2}{|c|}{ MOSENEW } \\
\hline Regime $1_{(t-1)}$ & 0.966459 & 0.033541 & 0.854576 & 0.145424 \\
\hline Regime $2_{(\mathrm{t})}$ & 0.196519 & 0.803481 & 0.043971 & 0.956029 \\
\hline $\begin{array}{l}\text { Constant } \\
\text { expected } \\
\text { durations }\end{array}$ & 29.81447 & 5.088576 & 6.876462 & 22.74225 \\
\hline \multicolumn{3}{|c|}{ TUSISE } & \multirow{4}{*}{\multicolumn{2}{|c|}{ NA }} \\
\hline Regime $1_{(t-1)}$ & 0.798889 & 0.201111 & & \\
\hline Regime $2_{(\mathrm{t})}$ & 0.027131 & 0.972869 & & \\
\hline $\begin{array}{l}\text { Constant } \\
\text { expected } \\
\text { durations }\end{array}$ & 4.972386 & 36.85858 & & \\
\hline
\end{tabular}

Source: authors' computation (2018).

For the SEMDEX index return, the probability of remaining in a bear period (0.966459) is greater than that of being in bull period (0.803481). In addition, the tendency for the market to transit from former (0.033541) to later is also lower than the other way around (0.196519). The bear regime lasts about 30 days while the bull regime lasts for just fivedays. Thus, the SEM has a higher likelihood of continuing in a bearish trend or market than a boom, which is a similar behavior tothe NGSE. Table 3 reveals that the likelihood of the MOSE being in an up period (0.854576) is lower than that of the down period (0.956029). However, the probability of moving from an up regime (0.145424) to a down regime is higher. The market is expected to stay in bull for about seven days compared to 23 days in bear conditions. It is noteworthy that there is a high tendency of moving from a bull to bear regime in all sampled markets except the JSE. The TUSISE results show that the probability that a stock return will stay 
in a bullish or bearish state are 0.798889 and 0.972869 , respectively. This means that the TUSISE tends to remain in bear market conditions than bull market condition. Moreover, the market shows a higher likelihood of moving from a bull condition to a bear condition. This is in line with the constant expected duration, which revealed that the market remains in a bearish state for approximately 37 days and in a bullish state for about five days.

\section{The DOW Effect (Weekend Effect)}

The result of the regime shift in the DOW effect for the selected African markets is presented in Table 3. $P$-values are marked with ${ }^{*}$, which indicates significance at the conventional 5 percent significant level. The results show evidence of a weekend effect in a bear market in the NGSEINDX returns, which is characterized by significantly low/negative Monday returns and positive/highest Friday returns. Tuesday and Thursday returns are also significantly negative and positive, but they are not as high as the weekend days. The weekend effect is not present in the bull period, but the opposite of the Monday effect is found with a positive and significant Monday return. The implication is that the weekend and Monday effects occurred during the bear period and disappeared during the bull period, indicating the appearance and disappearance of the calendar anomaly due to changing market conditions in the NGSE.

The JALSH result reveals that bear periods are not associated with a significant DOW effect while bull periods show the opposite of the popular weekend effect, as Monday's return is significantly positive and higher than those of the remaining days of the week, especially Friday. In essence, the presence of the DOW effect is found in bull periods, but the effect is absent in bear periods, in line with the AMH which states that profit opportunities appear during certain market conditions and disappear during other periods.

Regime switching is also present in the SEMDEX return series. The results in Table 2 show that apart from the Monday effect, the DOW effect is found in bear periods with Friday returns significantly higher than for other weekdays. The effect, however, disappears during bull periods, as all the weekdays possess insignificant coefficients at the traditional 5 percent significant level. This finding again supports the assertion that profit opportunity found in one regime may evaporate as the regime changes, as pointed out by the proponents of the new AMH.

The MOSENEW results reveal that the weekend effect is associated with bear markets in which both Monday and Friday returns are positive and significant, although the former is lower than the latter. The weekend effect is absent in bull periods, in which Monday returns are positive and significant, while Friday returns are not statistically significant. The TUSISE results show a switch between significant positive and negative Tuesday returns in bull and bear market, respectively. The results also reveal the presence of weekend effect in bear regimes with Friday returns significantly higher than for other weekdays. The observed weekend effect is, however, absent in bullish markets. 
Adefemi A. Obalade, Paul-Francois Muzindutsi

Table 3. Markov switching regression results of the DOW/Weekend effect

\begin{tabular}{|c|c|c|c|c|}
\hline \multirow{3}{*}{ Variable } & Coefficient & Std. Error & Coefficient & Std. Error \\
\hline & \multicolumn{2}{|c|}{ NGSEINDX } & \multicolumn{2}{|c|}{ JALSH } \\
\hline & \multicolumn{2}{|c|}{ Regime 1 BEAR } & \multicolumn{2}{|c|}{ Regime 1 BEAR } \\
\hline MON & $-0.069192^{*}$ & 0.022131 & -0.089246 & 0.117129 \\
\hline TUE & $-0.053029 *$ & 0.021989 & 0.085251 & 0.113472 \\
\hline WED & 0.028481 & 0.021363 & 0.069415 & 0.120344 \\
\hline THUR & $0.041856^{*}$ & 0.021881 & -0.000428 & 0.125887 \\
\hline FRI & $0.074485^{*}$ & 0.022024 & -0.184948 & 0.115064 \\
\hline \multirow[t]{2}{*}{ LOG(SIGMA) } & -0.651754 & 0.019604 & 0.623154 & 0.023604 \\
\hline & \multicolumn{2}{|c|}{ Regime 2 BULL } & \multicolumn{2}{|c|}{ Regime 2 BULL } \\
\hline MON & $0.210841^{*}$ & 0.110843 & $0.239956^{*}$ & 0.033715 \\
\hline TUE & 0.182613 & 0.109984 & 0.022718 & 0.033205 \\
\hline WED & 0.066527 & 0.108991 & 0.030983 & 0.033206 \\
\hline THUR & -0.008089 & 0.110714 & $0.126136^{*}$ & 0.032982 \\
\hline FRI & 0.138777 & 0.110761 & $0.078436^{*}$ & 0.032857 \\
\hline \multirow[t]{3}{*}{ LOG(SIGMA) } & 0.541531 & 0.026000 & -0.187243 & 0.016655 \\
\hline & \multicolumn{2}{|c|}{ SEMDEX } & \multicolumn{2}{|c|}{ MONENEW } \\
\hline & \multicolumn{2}{|c|}{ Regime 1 BEAR } & \multicolumn{2}{|c|}{ Regime 1 BULL } \\
\hline MON & 0.006451 & 0.010732 & $0.189437^{*}$ & 0.089286 \\
\hline TUE & -0.000549 & 0.010736 & -0.047017 & 0.090879 \\
\hline WED & $0.032889^{*}$ & 0.010893 & $0.202688^{*}$ & 0.091572 \\
\hline THUR & $0.035747^{*}$ & 0.010918 & 0.103449 & 0.089337 \\
\hline FRI & $0.054689 *$ & 0.010891 & 0.014334 & 0.089819 \\
\hline \multirow[t]{2}{*}{ LOG(SIGMA) } & -1.214262 & 0.015839 & 0.275315 & 0.029200 \\
\hline & \multicolumn{2}{|c|}{ Regime 2 BULL } & \multicolumn{2}{|c|}{ Regime 2 BEAR } \\
\hline MON & 0.162774 & 0.155238 & $-0.032332^{*}$ & 0.016487 \\
\hline TUE & 0.094545 & 0.155511 & -0.007450 & 0.016415 \\
\hline WED & 0.007180 & 0.149062 & 0.012594 & 0.016484 \\
\hline THUR & 0.267865 & 0.150165 & 0.019139 & 0.016939 \\
\hline FRI & 0.259889 & 0.152590 & $0.040913^{*}$ & 0.017188 \\
\hline \multirow[t]{3}{*}{ LOG(SIGMA) } & 0.601659 & 0.031716 & -0.883001 & 0.020684 \\
\hline & \multicolumn{2}{|c|}{ TUSISE } & & \\
\hline & \multicolumn{2}{|c|}{ Regime 1 BULL } & & \\
\hline MON & -0.042768 & 0.131530 & & \\
\hline TUE & 0.258358 & 0.133372 & & \\
\hline WED & -0.117327 & 0.130261 & & \\
\hline THUR & 0.103209 & 0.130218 & & \\
\hline FRI & 0.104296 & 0.135501 & & \\
\hline \multirow[t]{2}{*}{ LOG(SIGMA) } & 0.238085 & 0.046535 & & \\
\hline & \multicolumn{2}{|c|}{ Regime 2 BEAR } & & \\
\hline MON & 0.016983 & 0.014413 & & \\
\hline TUE & -0.026582 & 0.013958 & & \\
\hline WED & $0.038692^{*}$ & 0.013918 & & \\
\hline THUR & $0.059279^{*}$ & 0.013982 & & \\
\hline FRI & $0.086259^{*}$ & 0.014006 & & \\
\hline LOG(SIGMA) & -1.023128 & 0.018239 & & \\
\hline
\end{tabular}

*denotes significance(p-values) at 5\% Source: authors' computation (2018). 


\section{Discussion of Findings}

We found that all the markets except the JSE have a high tendency to be in a bearish state than otherwise. This finding throws up a question about the performance of African stock markets. The higher duration of the JALSH in a bull regime was also pointed out in a similar study by Rich (2018) for JSE All Share index and the Top 40. Since the JSE usually behaves like most developed markets, the longer duration in a bear regime could be an attribute of emerging or developing markets. The longer bearish trend may also be linked to illiquidity. The levels of liquidity of African stock markets have been very low, with South Africa being the only liquid market in the continent. Boako (2016) argued that illiquidity tends to cause serious retardation on the growth of markets. The longer bullish trend is also a sign that the South African economy is stronger than the other remaining markets whose longer bearish condition is an indication of a slow economy.

In addition, the weekend effect appears in bear regimes in the NGSE, SEM, MOSE, and TSE and disappears in bull regimes, and a reverse Monday effect is found in bull regimes in the JSE and disappears in bear regimes. The DOW effects also exhibit changing behavior where they are found. This study documents the Monday effect in Nigeria, which is in line with Osazevbaru and Oboreh (2014), and a reverse of the Monday effect in the JSE and Nigeria, in consonance with Du Toit, Hall and Pradhan (2018) and Bhana (1985). We also found a significant Friday effect in the SEM, which is consistent with Bundoo (2011). By contrast, studies such as Chukwuogor (2007) concluded that the DOW effect is absent in African countries, as our study has also revealed during certain market conditions. Therefore, some of our findings have been documented by previous studies. However, our study differs in that it shows how calendar effects are not always present where they have been documented, and how they are not always absent where they are not found. This regime-switching behavior of calendar anomalies has not been established before, especially in African stock markets; the only recognized studies which considered the market regime in African stock markets were carried out by Atsin and Ocran (2015) and Rich (2018) on the JSE. While the former found a reverse of the weekend effect in bull regimes, as reported in our study, Rich (2018) showed that there is no clear evidence of the DOW effect under any market regime. Unlike prior studies, we established that the DOW calendar anomaly is not a universal constant but time-variant, varying with the market condition in the selected African stock markets, and in line with the AMH.

It must be pointed out that calendar anomalies are found in bear regimes for the majority of markets. The findings may relate to the fact that, except for the JSE, all the selected African markets remain in a bearish rather than a bullish state. On the other hand, a comparable study carried out by Urquhart and McGroarty (2014) in the US also discovered that calendar anomalies such as the Monday and Halloween effects are stronger in down, bear, contraction and crash conditions compared to up, bull, expansions, and bubbles. Since our study also links calendar anomalies with bear regimes 
in the NGSE, SEM, MOSE, and TSE, it suggests that market conditions could have similar implications for calendar anomalies, whether the markets are developed or developing. More importantly, nonlinear models, such as the Markov switching model, appear to bring out the type of stock return behavior explained by the AMH, which cannot be adequately captured by a single state model.

\section{Summary and conclusions}

In line with the new $\mathrm{AMH}$, it is expedient to evaluate whether popular calendar anomalies behave differently under different market conditions/regimes. The switching model has been recognized as a powerful tool capable of accounting for changing market cycles or a regime switch in financial markets. Hence, this study examined time-varying calendar anomalies in selected African stock markets in bull and bear market conditions with the aid of the MSM. The study also estimated the probability of transitioning from one state to another and the time spent in a particular state. This study ranks among the foremost studies that not only investigated time changing calendar anomalies within the $\mathrm{AMH}$ context, but it was the first to apply a regime switching methodology in doing so. Thus, the study contributed to the growing knowledge of the AMH by documenting how calendar anomalies behave under bull and bear market situations in selected African markets. This finding is significant to the validation of the $\mathrm{AMH}$ in smaller stock markets and especially now when recent studies have advocated for African stock markets to be considered as a separate asset class.

We conclude that the DOW and weekend effects appear in one regime and disappear in another regime in the selected African markets, as rooted in AMH. The markets examined, therefore, may be described as adaptive markets, as calendar return behavior does not remain the same under different market conditions. Except for the JSE, all the selected African stock markets stay in the bearish rather than the bullish state. This has an implication for the performance of African stock markets. With many of the markets staying in bear rather than the bull regimes, we suggest that market regulators try to find a means of boosting market performance for the markets to play a meaningful role in economic development. Since the reasons for this behavior are outside the scope of this study, searching for possible reasons for a longer duration in a bearish state provides motivation for further empirical investigations.

With the observed similarity in market conditions and its implication for calendar anomalies in African stock markets, diversification between these markets may not yield a significant synergistic effect for the investors as far as exploitation of DOW and weekend anomalies are concerned. Market participants and portfolio managers should pay attention to market conditions when designing and applying their investment strategies. Active investment management may yield profits for investors and managers when the NGSE, SEM, MOSE, and TSE are in a bear regime, and the JSE is in a bull regime. However, investors may become passive in the subsequent regime 
when the anomaly weakens and the market becomes efficient. This study revealed that the DOW anomaly appears in certain market conditions and disappears in others, depending on the market. This means that African stock markets undergo conditions of inefficiency and efficiency, which supports the AMH. Our findings are in contrast with the findings of single state models through which the majority of African stock markets have been judged to be inefficient over the years.

\section{References}

AfricaTLF.com, (2016), Africa Equity Market Capitalisation, available at http://www. acm-consult.com/ (accessed: 12.10.2017).

Alagidede, P. (2009), Return Predictability in Africa's Emerging Equity Markets, "International Review of Financial Analysis", Vol. 18, No. 1, pp. 1-11.

Alagidede, P. (2013), Month of the Year and Pre-Holiday Effects in African Stock Markets, "Sajems”, Vol. 16, No. 1, pp. 64-74.

Alagidede, P., Panagiotidis, T. (2006), Calendar Anomalies in an Emerging African Market: Evidence From The Ghana Stock Exchange, available at: http://ideas.repec. org/p/lbo/lbowps/ 2006_13.html (accessed: 5.10.2017).

Atsin, J.A.L., Ocran, M.K. (2015), Calendar effects and market anomalies on the Johannesburg Stock Exchange, https://mpra.ub.uni-muenchen.de/87448/ (accessed: 2.11.2018).

Bhana, N. (1985), The Monday effect on the Johannesburg Stock Exchange, "South African Journal of Business Management", Vol. 16, No. 1, pp. 7-11.

Brishan, R. (2012), Calendar Effects on the Nine Economic Sectors of the Johannesburg Stock Exchange (A Master thesis), School of Economic and Business Sciences, University of the Witwatersrand, Johannesburg.

Brockman, P., Michayluk, D. (1998), The Persistent Holiday Effect: Additional Evidence, "Applied Economic Letters", Vol. 5, pp. 205-209.

Brooks, C. (2014), Introductory Econometrics for Finance ( $2^{\text {nd }}$ Ed.), New York: Cambridge University Press.

Bundoo, S.K. (2011), An Analysis of Stock Market Anomalies and Momentum Strategies on the Stock Exchange of Mauritius, "AERC Research Paper", Vol. 227, No. 1, pp. 1-48.

Chukwuogor, C. (2007), An econometric analysis of African Stock Market: annual returns analysis, day-of-the-week effect and volatility of returns, "African Journal of Accounting, Economics, Finance and Banking Research”, Vol. 1, No. 1, p. 26.

Diebold, F.X., Lee, J., Gretchen, C.W. (1994), Regime Switching with Time Varying Transition Probabilities, [in:] Hargreaves, C. (ed.), Nonstationary Time Series Analysis and Cointegration, Oxford: Oxford University Press, pp. 283-302.

Dragan, T., Martin, M., Igor, S. (2012), The Day of the Week Effect in South Eastern Europe Stock Markets, "Annals of the „Constantin Brâncuşi” University of Târgu Jiu, Economy Series", Vol. 3, pp. 20-24.

Fama, E.F. (1965), The Behaviour of Stock Prices, "Journal of Business", Vol. 37, No. 1, pp. 34-105. 
Fama, E.F. (1970), Efficient Capital Markets: A Review of Theory and Empirical Work, "Journal of Finance", Vol. 25, No. 2, pp. 383-417.

Filardo, A.J. (1994), Business-Cycle Phases and Their Transitional Dynamics, "Journal of Business \& Economic Statistics," 12, pp. 299-308.

French, K. (1980), Stock Returns and the Weekend Effect, "Journal of Financial Economics", Vol. 8, pp. 55-69.

Gibbons, M., Hess, P. (1981), Day of the week effects and asset returns, "The Journal of Business", pp. 579-96.

Goedhart, M., Koller, T., Wessels, D. (2005), Do fundamentals-or emotions-drive the stock market?, available at http://www.mckinsey.com/ (accessed: 12.10.2017).

Hakan, B., Halil, KI. (2001), The Day of the Week Effect on Stock Market Volatility, "Journal of Economics and Finance", Vol. 25, No. 2, pp. 181-193.

Hamilton, J.D. (1989), A New Approach to the Economic Analysis of Nonstationary Time Series and the Business Cycle, "Econometrica", Vol. 57, pp. 357-384.

Hansen, P.R., Lunde, A. (2003), Testing the Significance of Calendar Effects, "Working Paper”, Vol. 3, No. 3, pp. 1-39.

Hassan, R., Syed, A.S., Asad Saleem, M. (2015), Day of the Week Anomaly and Market Efficiency: Evidence from KSE-Pakistan, "International Journal of Business and Social Science”, Vol. 6, No. 9, pp. 69-75.

Helena, N. (2009), A Multifactor Approach in Understanding Asset Pricing Anomalies: An empirical study of the factor model in the Budapest Stock Market (Unpublished).

Julio, C.A.C., Beatriz, E.G.C. (2013), The Day-of-the-Week Effect: The CIVETS Stock Markets Case, "Journal of Applied Business and Economics", Vol. 15, No. 3, pp. 102116.

Lakanishok, J., Levi, R. (1982), Weekend Effects in Stock Returns: A Note, "Journal of Finance", Vol. 37, pp. 883-89.

Lakonishok, J., Smidt, S. (1988), Are Seasonal Anomalies Real? A Ninety-year Perspective, "Review of Financial Studies", Vol. 1, No. 4, pp. 403-425.

Lei, G., Gerhard, K. (2005), Calendar Effects in Chinese Stock Market, "Annals of Economics and Finance", Vol. 6, No. 5, pp. 75-88.

Lim, S.Y., Ho, C.M., Dollery, B. (2007), Stock Market Calendar Anomalies: The case of Malaysia, available at: .https://www.une.edu.au/_data/assets/pdf_ file/0008/67994/econ-2007-5.pdf (accessed: 15.10.2017).

Lo, A.W. (2004), The adaptive markets hypothesis: market efficiency from an evolutionary perspective, available at SSRN: https://ssrn.com/abstract=602222 (accessed: 31.08.2017).

Lo, A.W. (2005), Reconciling efficient markets with behavioral finance: the adaptive markets hypothesis, "Journal of Investment Consulting”, Vol. 7, No. 2, pp. 21-44.

Lo, A.W. (2012), Adaptive Markets and the New World Order, "Financial Analysts Journal", Vol. 68, No. 2, pp. 18-29.

Lo, A.W., Blume, L., Durlauf, S. (2007), The New Palgrave: A Dictionary of Economics (Second Edition), New York, Palgrave McMillan.

Lukas, M. (2009), Stock Market Seasonality: Day of The Week Effect and January Effect. (Thesis). 
Lukas, J. (2012), Analysis of stock market anomalies: US cross-sectoral comparison (Bachelor thesis), Charles University in Prague, Faculty of social sciences, Institute of economic studies.

Magnus, K. (2008), Seasonal Anomalies in the Swedish Stock Market from an Industry Perspective. Department of Economics, Lund University, Sweden.

Merrett, G.J., Worthington, A.C. (2006), An empirical note on the holiday effect in the Australian stock market, 1996-2006, School of Accounting and Finance, University of Wollongong, Wollongong 7 (11), pp. 1-10.

Martin, S. (2011), Characterization of Financial Time Series, "Research Note”, Vol. 11, No. 1, pp. 1-35.

Osazevbaru, H.O., Oboreh, J. (2014), The "Monday Effect" in Nigerian Stock Market: Evidence and Implication, "Journal of Social Sciences and Public Policy", Vol. 6, No. 1, pp. 1-8.

Pandey, F., Samanta, A. (2016), An Empirical Analysis of January Effect-Evidence from Indian Market, "International Journal of Innovative Research and Development", Vol. 5, No. 7, pp. 187-197.

Rich, S. (2018), Calendar Effects on the Johannesburg Stock Exchange: A Markov Switching Approach (M.Sc. Thesis), Gordon Institute of Business Science, University of Pretoria.

Rossi, M. (2007), Calendar anomalies in stock returns: Evidence from South America. (Bachelors' thesis), Lappeenranta University of Technology Department of Business Administration Section of Finance.

Rystrom, D.S., Benson, E.D. (1989), Investor Psychology and the Day-of-the-week Effect, "Financial Analysts Journal", Vol. 45, No. 5, pp. 75-78.

Shakeel, K., Douglas, M., Chimwemwe, C. (2013), Changing Patterns in The Day-Of-TheWeek Effects in African Stock Markets, "International Business \& Economics Research Journal", Vol. 12, No. 10, pp. 1157-1174.

Shiok, Y.L., Chong, M.H., Brian, D. (2007), Stock Market Calendar Anomalies: The Case of Malaysia, http://www.une.edu.au/economics/publications/ecowps.php (accessed: 6.10.2017).

Thaler, R.H. (1999), The End of Behavioural Finance, "Financial Analyst Journal", Vol. 55, No. 6, pp. 12-17.

Toit, E. Du, Hall, J.H., Pradhan, R.P. (2018). The day-of-the-week effect: South African stock market indices, "African Journal of Economic and Management Studies", Vol. 9, No. 2, pp. 197-212.

Umar, B.N. (2013), The Day of the Week effect on stock market returns and volatility: Evidence from Nigeria and South Africa, Munich Personal RePEc Archive. Online at http://mpra.ub.uni-muenchen.de/48076/ (accessed: 8.02.2018).

Urquhart, A., McGroarty, F. (2014), Calendar effects, market conditions and the Adaptive Market Hypothesis: Evidence from long-run U.S. data, "International Review of Financial Analysis", Vol. 35, pp. 154-166.

Vergin, R.C., Mcginnis, J. (1999), Revisiting the holiday effect: Is it on holiday?, "Applied Financial Economics", Vol. 9, No. 5, pp. 477-482.

Wing-Keung, W., Aman A., Nee-Tat, W. (2006), The Disappearing Calendar Anomalies in the Singapore Stock Market, "Lahore Journal of Economics, Department of Economics", The Lahore School of Economics, Vol. 11, No. 2, pp. 123-139. 


\section{Streszczenie}

\section{Hipoteza rynku adaptacyjnego i efekt dnia tygodnia na giełdach afrykańskich: model przełącznikowy Markowa}

W oparciu o hipotezę rynku adaptacyjnego, w niniejszym opracowaniu zbadano, w jaki sposób efekt dnia tygodnia działa w fazie bessy i hossy na afrykańskich rynkach akcji oraz określono prawdopodobieństwo bycia w fazie bessy i hossy na każdym z tych rynków. Jako technikę analityczną przyjęto model przełącznikowy Markowa. Wyniki pokazują, że na wszystkich rynkach efekt dnia tygodnia pojawia się w jednej fazie i znika w drugiej, zgodnie z hipotezą rynku adaptacyjnego. Wreszcie, wszystkie rynki, z wyjątkiem giełdy w Johannesburgu, mają wyższą tendencję do bycia w fazie bessy niż hossy. Nasze ustalenia pokazują, że aktywne zarządzanie inwestycjami może przynosić zyski inwestorom inwestującym na większości rynków afrykańskich w fazie bessy.

Słowa kluczowe: efekt kalendarza, hipoteza rynku adaptacyjnego, afrykańskie rynki akcji, model przełącznikowy Markowa 